\title{
Green Roofs in Urban Landscapes ${ }^{1}$
}

\author{
Eva Worden, Diana Guidry, Annabel Alonso Ng, and Alex Schore ${ }^{2}$
}

Growing apace with urban populations is the dilemma of how to create and sustain a healthy urban ecosystem. Cities increasingly struggle to cope with the urban heat island effect, stormwater runoff, altered weather patterns, air pollution, loss of tree canopy and greenspace, noise, and loss of wildlife habitat. Green roofs, which are specially designed landscapes atop buildings, can provide solutions to many of these problems as well as enhance the quality of life for urban residents.

Green roof history stems from ancient times. One of the wonders of the ancient world, the great Hanging Gardens of Babylon, built by King

Nebuchadnezzar II in about 600 B.C., were a mountain-like series of planted terraces. More recent forebears of engineered green roofs are the sod-covered homes of Northern Europe, where sod roofs and walls have been used as construction materials for hundreds of years. Early European settlers in the Great Plains of North America built "soddies," or sod-covered homes, during the period of westward expansion.

The development of contemporary approaches to green roof technology began in urban areas of Germany over 30 years ago. In the United States, many green roofs are in place. Chicago and Atlanta have municipal buildings retrofitted with green roofs.

Green roofs can provide numerous benefits, including:

- Reducing the quantity and pollutant levels of stormwater runoff, and consequently decreasing the need to expand community water treatment infrastructure

- Filtering chemical air pollutants and physically capturing airborne particulates

- Moderating urban heat island effects

- Creating habitats for birds and invertebrates

- Increasing thermal insulation of buildings, thus reducing heating and cooling costs

- Reducing costs of roofing maintenance and replacement

- Providing human health benefits through quieter interior environments, improved air quality, and therapeutic benefits resulting from viewing or caring for plants

1. This document is ENH 984, one of a series of the Environmental Horticulture Department, Florida Cooperative Extension Service, Institute of Food and Agricultural Sciences, University of Florida. Original publication date September 2004. Visit the EDIS Web Site at http://edis.ifas.ufl.edu.

2. Eva Worden, Assistant Professor and Extension Specialist; Diana Guidry, Annabel Alonso Ng, and Alex Schore, Environmental Horticulture Students, Fort Lauderdale Research and Education Center, 3205 College Avenue, Fort Lauderdale, FL 33314.

The Institute of Food and Agricultural Sciences (IFAS) is an Equal Employment Opportunity - Affirmative Action Employer authorized to provide research, educational information and other services only to individuals and institutions that function without regard to race, creed, color, religion, age, disability, sex, sexual orientation, marital status, national origin, political opinions or affiliations. For information on obtaining other extension publications, contact your county Cooperative Extension Service office. Florida Cooperative Extension Service / Institute of Food and Agricultural Sciences / University of Florida / Larry R. Arrington, Interim Dean 
- Increasing usable space for meetings, recreational activities, and community events

- Expanding opportunities for urban agriculture and community food security

City governments, large corporations, and other entities with significant financial resources are sponsoring green roof programs and leading the way in promoting the adoption of green roof technologies. In New York City, the Earth Pledge Green Roofs Initiative has a mission of spreading and supporting the installation of green roofs. With support from the U.S. Environmental Protection Agency, they have established a network of stakeholders, educators, developers, and government agencies in order to facilitate the expansion of green roofs. The city of Chicago installed a green roof on its city hall in 2001. The city co-sponsored, with Green Roofs for Healthy Cities, the First Annual North American Green Roof Conference in 2003. The Ecoroof Program in the city of Portland, Oregon, promotes green roofs by researching ecoroof technologies and providing information and technical assistance to community members. The Ford Motor Company has installed a 10.4-acre green roof atop its assembly plant in Dearborn, Michigan.

\section{Intensive and Extensive Green Roofs}

All well-designed green roofs include subsystems responsible for drainage, plant nourishment and support, and protection of underlying waterproofing systems. Green roof drainage design must both maintain optimum growing conditions in the growth medium and manage heavy rainfall without sustaining damage to the roof due to erosion or pooling of water. The engineered substrate medium must meet exacting requirements for numerous parameters, including grain-size distribution, void ratio, and moisture retention. Plants selected for either intensive or extensive green roofs would be determined by site-specific "right plant-right place" requirements.

There are two main types of green roofs: intensive and extensive. Whether to use an intensive or extensive green roof depends on the structural capacity of the building and on the project goals.
Intensive green roofs are traditional-style roof gardens, with large trees and shrubs. They often are accessible to the public and can include garden paths, seating, and other features that make the roof an outdoor room. Since they are meant to be similar to a park, they generally are on flat roofs. As suggested by the name, they are labor-intensive, requiring irrigation and continuous maintenance. Intensive roofs are multi-layer constructions, typically installed over concrete roof decks. They require substantial structural capacity: approximately 8 inches to 4 feet of soil depth, and support of roof weight loads from 80-150 pounds per square foot.

Extensive roofs are not designed for public use but are more for environmental benefits. They help to mitigate the effects of urbanization on water quality, often dramatically, by filtering, absorbing or detaining rainfall. Extensive green roofs can have a soil depth of approximately 1 to 7 inches and can carry weight loads of 15 pounds per square foot. They are constructed of a lightweight soil medium and are underlain by a drainage layer and a high quality impermeable membrane that protects the building structure. Extensive green roofs can be installed over various roof decks; however, a structural engineer should always first inspect the structure to determine its weight load limitations.

The soil of the extensive green roof is planted with a specialized mix of plants that can thrive in the harsh, dry, high temperature conditions of the roof and tolerate short periods of inundation from storm events. Wildflowers, grasses, and sedums are popular selections for creating a "roof meadow." Sod usually is not used for extensive roof applications because it is maintenance-intensive and requires regular mowing, irrigation and fertilization.

The ideal roof slope for an extensive green roof is between 5 degrees (1:12) and 20 degrees (4:12), because water drains naturally due to gravity. A flat roof requires an additional layer to drain excess water away from the root zone. Since extensive green roofs are not designed for public use, they can be angled up to 45 degrees, if a raised grid structure is used to stabilize the growing medium until plants form a thick vegetation mat. 
Extensive green roofs require only periodic maintenance. Plants may need to be irrigated during the establishment period, usually for 6 months, and only if natural precipitation is insufficient. On a large roof, it may be economical to lay drip irrigation tubing during installation to allow for uniform watering during establishment and in occasional periods of extreme drought. Occasional weeding may also be required in the establishment period. Application of slow-release fertilizer once or twice per year is sufficient for plant nutrient requirements.

\section{Financial Considerations}

The cost of a green roof can be 30-60\% higher than that for a traditional roof. While green roof construction is similar to construction for a conventional gravel-ballasted roof, the soil substrate and plants are additional expenses. The use of plant plugs in extensive green roofs increases labor costs because every plug must be planted individually. It is possible that costs for extensive green roofs in the U.S. may soon be reduced by one-half, based on the demand for installation and the availability of the soil substrate and plants. Currently, funding for green roofs is available through the Environmental Protection Agency's Clean Water Act Section 319 (non-point source pollution) grant program, and through local environmental funding initiatives.

The growing adoption of green roofs presents unique business opportunities. Professional landscapers and nursery growers can create a specialty niche that caters to progressive clients. Beyond commercial accounts, green roofs have vast growth potential in residential landscape sectors. Additionally, jobs and revenue may be produced by suppliers and manufacturers of specialized roofing materials and services.

Potential benefits for developers may be increased property values; increased market exposure; a faster approval process for new projects, reduced stormwater/wastewater charges, reduction in the size of stormwater management facilities, grants related to energy efficiency or green roofs, satisfaction of minimum parkland requirements, and greenhouse gas emissions trading credits from energy savings.
The significant benefits of green roofs, such as stormwater retention and improved life quality, may be difficult to calculate. However, such benefits, combined with improved roof longevity and thermal insulation of a green roof can outweigh the increased installation costs for most green roof projects.

\section{Resources}

- Ecoroof Program. City of Portland, Oregon. www.cleanrivers-pdx.org/clean_rivers/ ecoroof.htm

- Emory Knoll Farms. Supplier of plants and plant expertise for extensive green roof systems. www.greenroofplants.com

- Ford Motor Company. Green roof of 10.4 acres at Dearborn Truck Plant final assembly building. http://www.ford.com/en/company/about/ corporateCitizenship/ principlesProgressPerformance/our-actions/ rouge-environment.htm

- Greengrid. Flexible green roofing system. www.greengridroofs.com

- Green Roofs: The greenroof industry resource portal. www.greenroofs.com

- Green Roofs for Healthy Cities. Network of public and private organizations. www.greenroofs.org

- Greening Gotham: A Project of the Earth Pledge Green Roofs Initiative. www.GreeningGotham.org

- Roof Gardens: History, Design, and Construction. Theodore Osmundson, FASLA. W.W. Norton and Company, Inc., New York. 1999.

- Roofscapes, Inc. Green technology for the urban environment. www.roofmeadow.com 